\title{
Postcolonial Singularity and a World Literature Yet-to-Come
}

Lorna Burns (University of St Andrews)

Imb21@st-andrews.ac.uk

Gayatri Spivak's Death of a Discipline advocated critical reflection on the field of comparative literature in light of the ethical demands made on literature and indeed literary criticism in a context where border crossings and transnational encounters risk reinscribing imperialist ideologies. The planetary vision foregrounded in that work explored the productive space inbetween a universalizable concept of alterity and the specificity of subaltern experience. Yet how this dual vision might inform a resurgent field of world literature studies has not yet been sufficiently understood. The works of Franco Morretti, Pascale Casanova, Emily Apter, and David Damrosch have become touchstones in contemporary world literature debates. Spivak, as she acknowledges, is "one of them", one of those "thinking to respond to a "crisis in Comparative Literature'” (An Aesthetic Education 446) and, yet, somewhat marginalised. None of these scholars form a homogenous group and debates concerning the relative merits of close and distant readings, canon formations, and the literary capitals of a reformulated world of letters will no doubt continue apace, however Spivak's perceived difference is key: "My difference", Spivak writes, "is that these critics all want to classify in a cruder and less informed way than the old literary historical and generic classificatory attempts. [Whereas her work] comments on the universalizability and generalizing characteristics of the literary" (446). In other words, what is at stake in Spivak's intervention in world literature and what marks her difference is alterity and ethics. Hers is a reframing of world literature that retains the critical gains made by postcolonial theory and suggests that the work of world literary analysis ought not necessarily be de/prescriptive (classifying and ordering) but might involve a contestation of the power relations that structure the world.

This essay considers the challenge posed by Spivak to rethink world literature along postcolonial lines as an ethical encounter with alterity. Literature by this account is no mere reflection of an extant state of affairs but an active force in the production of revolutionary lines of flight that undermine ideological hegemonies and open up "a future that is not a future present" (Spivak, An Aesthetic Education 66). As my language here suggests Spivak is not 
the only thinker to inform this line of argument, and this essay takes up the writing of four further interlocutors as it sketches out these ideas: Pascale Casanova, whose concept of the world republic of letters raises important questions about the relationship between the singularity of literature and the world, but which is ultimately compromised by Spivak's own understanding of singularity; Fredric Jameson, whose controversial discussion of the allegorical function of "third world literature" nevertheless counterpoints the limited understanding of national literature offered by Casanova - in Jameson the nation is not prescribed but a future potentiality yet to come; Gilles Deleuze, who, despite different forms of scepticism from both Casanova and Spivak, nevertheless offers a productive way to rethink world literature in a process of becoming; and finally Édouard Glissant whose work is at once informed by a deep understanding of Deleuzian thought and oriented towards a planetary or "relational" vision of difference that, like that of Spivak, demands an ethical, imaginative response from literature as literature.

\section{Postcolonial Futures}

Spivak's conviction in literature's capacity to inform a collective imagining of an "undecidable future" (An Aesthetic Education 474), "a future that is not a future present" (66) but one which is unforeseeable, hits upon a central strand of postcolonial thought, as I argued, for example, in Contemporary Caribbean Writing and Deleuze. By way of a range of Caribbean writers from early twentieth-century surrealists (René Ménil, Aimé Césaire, and Suzanne Césaire), to the region's predominant figures (Wilson Harris, Derek Walcott and Édouard Glissant) and contemporary less-well known ones (Nalo Hopkinson, Pauline Melville, Robert Antoni), that work argued that the idea of a future which cannot be anticipated by the structural limitations of the present offers a conceptual basis for rethinking postcolonialism as an always deferred, but never utopian, "yet-to-come". Writers such as Glissant and Harris have made much of this temporal caesura as the grounds of a new, creolized identity that while borne out of a painful past is nonetheless creative. Wilson Harris' novel Jonestown, for example, reimagines the mass suicide of nine hundred members of the People's Temple in 1978 in Guyana as both an archetypal sign of a will to dominate and the potential ground for the imagining of a future which transcends the destructive pattern of domination and conquest that the novel traces. As 
the narrator notes, "continuities running out of the mystery of the past into the unknown future yield proportions of originality, proportions of the "genuinely new"' (Harris, Jonestown 6). Similarly, in Caribbean Discourse, Glissant proposes a "prophetic vision of the past" (64), implying that the past may be reread in such a way as to reveal something new. This central concern with newness and creativity is reflected in his concept of creolisation as that which cannot be reduced to a hybrid synthesis but is rather the marker of an on-going process (Relation): "Creolization is unpredictable, [...] opens on a radically new dimension of reality [... it] does not produce direct synthesis, but 'résultantes', results: something else, another way" (Glissant, "Creolization" 270). ${ }^{1}$ These writers interrogate the role that the past plays in shaping the present and express a desire for something more than the preservation of an imperialist framework which opposes self and other, centre and periphery. In this respect they echo Albert Memmi who, in The Colonizer and The Colonized, characterised the colonial situation as one of ressentiment, where both coloniser and colonised are trapped in and externally defined by their negative relation to one another. Revolt may be "the only way out of the colonial situation" (Memmi, The Colonizer 172), but it too must eventually give way to something more than a continuation of the same: "In order to witness the colonized's complete cure, his alienation must completely cease. We must await the complete disappearance of colonization - including the period of revolt" (185). In other words, insofar as revolt preserves the oppositional binary of self and other it remains bound to the fundamental structure of colonisation: "The colonized's self-assertion, born out of a protest, continues to define itself in relation to it [the colonizer]. In the midst of revolt, the colonized continues to think, feel and live against and, therefore, in relation to the colonizer and colonization" (183). Described here is a condition that Nietzsche would characterise as one of ressentiment: both "master" and "slave" dominated by an external force. Alienation will be overcome only with "the complete disappearance of colonisation" not merely in the political sense (national independence) but ontologically as the reactive will-to-dominate gives way to the creative and affirmational will-to-power. ${ }^{2}$ Viewed in this light, the concern for newness, creativity and prophetic visions of the past is bound up with both anticolonial struggle and an ontological condition of postcoloniality that is always a deferred promise (the complete disappearance of the political and epistemic structures of colonialism). 
Not only Spivak, Harris and Glissant, but also the non-dialectical philosophy of Deleuze informs this argument: his rejection of philosophies which function through the negative and aim towards the recuperation of difference. ${ }^{3}$ In his rejection of Hegelian thought, for example, Deleuze reveals the basis of an affirmational philosophy in the counterpoint of Bergson: "in Bergson [...] the thing differs with itself first, immediately. According to Hegel, the thing differs with itself because it differs first with all that it is not" (cited in Hardt, Gilles Deleuze 7). This is the difference between a reactive ontology in which being is defined by an external relation and a state of affairs that actively defines itself. Or, in Glissant's words: "Such a startling condition, that a man withstands being so hunted by an artifice, that simply to say what he is requires him to proclaim what he isn't, and that before naming himself he has to incite the names that fasten him from such a distance" (Poetic Intention 27). The distinction at work here is one made between an active force that differentiates itself in the first instance and a reactive force dominated by others. To overcome alienation, in Memmi's sense, Glissant suggests that the "French Caribbean individual does not deny the African part of himself" but nor does he "have, in reaction, to go to the extreme of celebrating it exclusively. He must recognize it" while understanding that "another reality has come about" (Caribbean Discourse 8). In other words, although the individual is not bound to react to external forces, the model is not one of non-relation. Like the Nietzschean übermensch, the individual appropriates those forces that affirm their life; that can be utilized in the creation of another, new, creolised reality.

It is a sign of prevailing active forces that the disjunctive process of creolisation is creative of the genuinely new. Like Harris and Glissant, Spivak has drawn attention to the role of creativity in the face of an over-determining colonial past. Her concept of "teleiopoiesis", defined as "imaginative interruptions in structures of the past" (An Aesthetic Education 369), finds resonance in both Glissant and Harris who see in history much more than a continuation of the same. Further, Spivak's claim that "[w]e who are from subordinated cultures must abuse the new as agents as we mourn the past with appropriate rites as subjects - a necessary but impossible task of cultural translation" (369), puts a similar onus on the new as a site of postcolonial struggle. In Spivak, the present is caught in a double bind between a past that should not be forgotten and a future that has the capacity to become new, become 
postcolonial in the sense anticipated by Memmi. But it is of course a reading of Jamaica Kincaid's novel Lucy, or more specifically "the singularity of the language of the novel" (369), that leads her to this point. And this brings me to the main strand of this essay: the specific work of literature as such, as well as that of postcolonial and world literary criticism.

\section{Literary Singularity}

The role of literature has remained a key point of contention in contemporary postcolonial studies. Spivak insists on the necessity of "rhetorical reading practices because I believe, in an irrational, utopian, and impractical way, that such reading can be an ethical motor that undermines the ideological field" (352). This sentiment, I would suggest, remains imperative in light of a resurgent field of world literature comparativism insofar as the recognition of the ethical and counter-hegemonic value of literary culture retains key coordinates of postcolonial criticism. Spivak's "conviction that sensitive approaches to literature enhance rather than detract from the politics" (351), in other words, is an attempt to realise the role that literature and reading can play in the reimagining of the world - undermining a hegemonic or oppressive ideological field without reductively conflating the literary and the political. Pascale Casanova puts this in a slightly different light in "Literature as a World" when she asks, first, "[i]s it possible to re-establish the lost bond between literature, history and the world, while still maintaining a full sense of the irreducible singularity of literary texts? Second, can literature itself be conceived as a world?" (71). In this, Casanova seeks to negotiate the poles of literary criticism torn between, on the one hand, an "internal, text-based literary criticism" which assumes "the total rupture between text and world", and on the other, an "external criticism that runs the risk of reducing the literary to the political" (71). For Casanova, however, postcolonial criticism is undoubtedly of the latter camp since it "posits a direct link between literature and history, one that is exclusively political" (71).

To shift from world literature debates to postcolonial ones, "second-wave" postcolonialists such as Aijaz Ahmad, Benita Parry or Neil Lazarus would no doubt be surprised to learn that postcolonial criticism, as a whole, is guilty of reducing the literary to the political. That second wave, informed by a decidedly Marxist stance against the deconstructivist tendencies of Homi Bhabha, Gayatri Spivak and Edward Said, were 
expressly opposed to the latter's focus on language and discourse rather than "real world" politics. As Benita Parry writes: "Those who have been or are still engaged in colonial struggles against contemporary forms of neo-colonialism could well read the theorizing of discourse analysts with considerable disbelief [... at such] incuriosity about the enabling socio-economic and political institutions and other forms of social praxis" (Postcolonial Studies 26). Casanova's work, and in particular The World Republic of Letters, which sets out an impressive survey of the evolution of world literature from the late-sixteenth century to the contemporary period, necessarily uses broad brush strokes. In that respect, I am less troubled by her generalisation of postcolonial criticism as "exclusively political" and therefore blind to the specific value of literature as such (the singularity of its language, as Spivak maintains), than the extent to which her work successfully answers its own call "to reestablish the lost bond between literature, history and the world, while still maintaining a full sense of the irreducible singularity of literary texts".

Casanova poses an important question, one that bears particular relevance for postcolonial studies. Surveying the poststructuralist/Marxist debates that have characterised divisions within the field of postcolonial studies, Peter Hallward has suggested that, "[t]o argue that 'literary criticism must become social theory and social criticism' is surely to condemn the field, in the end, to the supervision of ultimately specified social interests and cultural identities" (Absolutely Postcolonial 334). While Absolutely Postcolonial poses a far reaching critique of the field of postcolonial studies, one that I along with Spivak would want to resist, Hallward here recognises the proximity of (postcolonial) literary value to the text's singularity. ${ }^{4}$ Furthermore, "[w]hat is distinctive about literature is its capacity to invent new ways of using words [...], at a disruptive distance from inherited norms and expectations" (xx). The singularity of literature alongside its capacity to disrupt the ideological field ground postcolonial criticism and theory, and to that extent Hallward, Spivak and Casanova would seem to agree: literary criticism should seek to re-establish "the lost bond between literature, history and the world" (the specific) "while still maintaining a full sense of the irreducible singularity of literary texts" (Casanova, "Literature as a World" 71). Hallward will ultimately seek to unpick the concept of postcolonial singularity in ways that are all too familiar to those acquainted with his criticism of Deleuze: a Deleuzian singularity will ultimately lead out of this 
world, deterritorialising, despecifying. ${ }^{5}$ Elsewhere I have challenged this reading of Deleuze and postcolonialism, and suggested that Deleuzian singularity ought not to be equated with a process of deterritorialisation alone (cf Burns 2012). Interestingly, however, Casanova leads us towards a similar misreading of Deleuze and Guattari, and ultimately her own account of the singularity of literature is one that puts pressure on the idea that the singular and the specific might happily inhabit the same space.

In The World Republic of Letters Casanova maintains that the singularity of literature is measured by its distance from the political, and she poses a trajectory that moves from an initial relation between literature and politics (in short, national literature bound up with nationalist struggle) to the independence of literature from politics. That independent republic of letters, however, is not a unified space but one marked, much like the political world, by what we might recognise as uneven and combined development: there is a single autonomous literary space in which "literary capital" is unevenly distributed (literary capital might be measured by publishing houses, prestigious prizes and the capacity to confer literary value, set trends, or canonise). The first half of The World Republic dwells on Paris as the single most significant centre of literary capital, but the postcolonial interest will be drawn to the second half in which Casanova discusses the outliers and "small literatures". She is of course referencing Kafka in this designation but also very decidedly not using the other possible translation of klein literature - minor literature. In this she is very consciously drawing a line between her approach to literatures of the margins and Deleuze and Guattari's minor literature, an issue that I will return to. ${ }^{6}$

Casanova's definition of small literatures or literatures which emerge from "deprived spaces" (The World Republic 191) turns upon the moment of nationalist struggle and decolonisation when literature and politics are united in a common cause. In such circumstances, the writer becomes spokesperson for their people, participating in the articulation of an independent national identity. Such is the case, Casanova argues, with Chinua Achebe, a writer who stressed the necessity of the interrelation of literature and politics (rather than a "pure art" with no relation to the world): "Chinua Achebe was to become the bard and repository of Nigerian national history" (196) and his novel Things Fall Apart was "[a]t once a realist, didactic, demonstrative, and national novel, [displaying a] dual ambition 
[which] was to provide Nigeria with a national history and to teach this history to the people" (196). To stress the role that literature plays in creating an imagined national community is no new idea, but in answer to Renan's question "what is a nation?" here Casanova seems to take for granted that the nation (in the literary space) is identical to the political one. ${ }^{7}$ In other words, the choice of Achebe as an example of Nigerian national spokesperson is simplistic. Nigeria, Achebe's works underscore, was a product of British imperialism: a nation-state imposed on the diverse cultures, traditions and languages that distinguish the lbo, Yoruba and Hausa tribes (among others). Things Fall Apart published shortly before Nigerian independence retells the destruction of a particular lbo tribe as the colonisers impose their own culture and political systems on them, systems which gained a hold not by force of numbers but through the participation of, in particular, the northern Hausa tribes. ${ }^{8}$ The state apparatus that remained at independence encouraged Hausa dominance in government, an imbalance that in part fuelled the Nigerian Civil War of 1967-1970. During this conflict Achebe was vocal in his support of an independent lbo nation of Biafra and was subsequently exiled from Nigeria after the reinstatement of government. How far, then, can Achebe be aligned with the role of spokesperson of the new Nigeria? The problem with Casanova's account of national literature is that it assumes that there is only one nation and that it is identical to the recognised political entity. ${ }^{9}$

There is, I think, another issue with Casanova's approach. In the case of small literatures she traces a trajectory that begins with a direct relation between politics and literature. In this first moment, the close connection between literature and politics is expressed through texts that are distant from literary modernity: they use conservative narrative forms like realism and are thus vulnerable to political and nationalist appropriation (they become vehicles for the repetition of the officially sanctioned national narrative). The literature of the centre, on the other hand, is one that is expressly depoliticised and in it we will find "the almost complete disappearance of popular or national themes, the appearance of 'pure' writing - texts that, freed from the obligation to help to develop a particular national identity, have no social or political 'function'”, such as experimental writing (Casanova, The World Republic 199-200). This is where Casanova's argument with Deleuze and Guattari's minor literature comes into play, most notably in terms of its political dimension: 
Literary texts in these small countries are inevitably produced, Kafka has argued, in proximity with politics [... where] individual concerns rapidly become collective: every text has a political character, since one seeks to politicize (which is to say, to nationalize), to shrink the frontier that separates the subjective - the domain reserved for literature in large countries - from the collective. (201)

The sleight of hand here is one that conflates politics with nationalism. Experimental or otherwise innovative literatures, by the same token, "have no social or political function" because as redefinitions of what constitutes modernity they belong to the autonomous literary space. Deleuze and Guattari's minor literature must be dismissed as an inaccurate representation of Kafka's true literary project as a national writer: "They project upon Kafka their view of politics as subversion, or 'subversive struggle', whereas for him, in the Prague of the early twentieth century, it was identified solely with the national question" (201).

There are two points on which I would test Casanova's argument: first, the reduction of politics in postcolonial nations to nationalism; and second, the suggestion that Deleuze and Guattari view politics only as subversion. In relation to the first, my concern is not that national consciousness is not a key stage in decolonising the mind (to evoke both Fanon and Ngũgĩ), but that Casanova assumes both a cohesive notion of the nation while overlooking competing or marginalised perspectives within that narrative, and refuses the idea that literature might participate in the construction of a national consciousness that has yet to come into existence. The interesting counterpoint in this respect is Frederic Jameson's "Third-World Literature in the Era of Multinational Capitalism". Criticisms against what was taken to be a reductionist and prescriptive account of "all third-world literature" (Jameson, "Third-World Literature" 69) have been well rehearsed, but if, like Neil Larson (Determinations 19), we take his argument as one which proposes a structural rather than essential tendency in literatures drawn from a particular set of social, economic and historical circumstances, then we are not so far from Casanova's suggestion that literature evolves from a point at which there is a clear and direct correlation between literature and politics - where the nationalist struggle of the people is reflected in literary works which help validate the nation's distinctive, independent voice. ${ }^{10}$ 
Unlike Jameson, however, Casanova refuses the idea that literature can participate in a revolutionary refiguring of the nation. Deleuze and Guattari are criticised in this respect because "they hold that Kafka was political, but only in a prophetic way; he spoke of politics, but only for the future, as if he foresaw and described events to come" (Casanova, The World Republic 204). In Casanova's republic, revolutions occur only in literary form and at the point at which literature is most detached from politics. Literature when it is political will be predictable; "it will use the most conservative narrative, novelistic and poetical forms" (199); the writer will be in effect a historian, narrating "national history and controversies", and "defend[ing] a certain idea of their country" (191). The point at which the writer's narrative of the nation no longer strikes a chord with the populace they move toward a greater autonomy. Jameson, on the other hand, insists that to the extent that third world literature participates in national politics it is has a creative, future-oriented role. The allegorical function of literature is not of they type we see in The Pilgrim's Progress, which, Jameson suggests, presents us with a rather "a one-dimensional view of this signifying process" and instead he proposes a more complex model in which "such equivalences are themselves in constant change and transformation at each perpetual present of the text" ("Third-World Literature" 73). In the example he gives of the short stories of Lu Xun, the writer's allegory does not enforce a unified and fixed image of the nation, rather, China emerges as both persecutor and victim. Thus we should remember "the capacity of allegory to generate a range of distinct meanings or messages, simultaneously, as the allegorical tenor and vehicle change places" (74). In this way the singularity of language in the novel, how it works, is the basis of the text's transformative capacity and, as such, Jameson asks if literature and literary criticism might in themselves "be a political act, with real consequences" (74). This would be a call to rethink the "relationship of a narrative text to futurity and to some collective project yet to come", which would not be "merely a formal or literary-critical issue" (77). In other words, if the text is read as an allegory of the nation, here Jameson offers the possibility that the nation in question might not yet exist, it might be "a collective project yet to come", and further that literature and literary criticism might be part of the process of imagining that future collective. National allegories such as Lu Xun's short stories, Jameson argues, can both reflect the current state of the nation (oppressive, hierarchical, traumatised) and suggest the future 
possibility of a Chinese nation in which the collective forms a more equal society. For Jameson, the very tension between the nation in its current form, marked in many cases by the history of imperialism and colonialism, and what it might become is key since it is "by way of a complex play of simultaneous and antithetical messages, that the narrative text is able to open up a concrete perspective on the real future" (77).

That yet-to-come, as noted previously, is fundamental to an understanding of, specifically, postcolonial literature and theory. As we have seen in the case of Achebe, at the moment of decolonisation literature is involved in the evaluation of what form the nation might take, of where the boundaries will be drawn, of who belongs. There is a sense in which the postcolonial is precisely this yet-to-come: Glissant, for example, suggests that in the Caribbean the writer's task consists of "building a nation", of "assembl[ing] a common will, by which we might be forged" (Poetic Intention 171), and that this will be achieved in a language that is "[n]ot codified, since it will result from the effort of the collective body that we aren't yet" (179). Postcolonial literature and theory exists in the tension between a present marked by both colonial legacies and neo-colonial interests and a genuinely postcolonial future in which the whole imperial framework is abandoned. This is not to say that such a situation is easily attainable, hence the necessity of a literature that is a striving for-prophetic, revolutionary, but not utopian. However objectionable Jameson's essentialising claims for "all third world literature", his decoupling of literature from nationalist representation via an attentiveness to the singularity of language (how it works) presents an alternative to Casanova for whom singularity is always a measure of detachment from the political. In other words, the autonomous republic of letters represents, in Hallward's critical sense, a singular constellation that leads out of this world.

Spivak's own exploration of singularity might be employed to better understand the distinction at work here between Jameson and Casanova. In her reading of Kincaid's Lucy, Spivak echoes Jameson's sense that literary criticism might itself constitute a political engagement by viewing the former as an enhancement of political struggle. By focusing specifically on "the singularity of language" (An Aesthetic Education 354), Spivak rereads Lucy not merely as a reinscription of colonial oppression or an emergent anti-colonial subjectivity - both of which might view the novel as reflecting Antigua's colonial history or 
national decolonisation respectively - but, in the singularity of its language (how the text works), as foregrounding something akin to the imaginative imperative for newness that, in their distinct ways, Glissant, Harris and Jameson have argued for. "If we are reading only for 'what the plot called for', the exchange between characters as 'real' people can be read as expected: determined by received ideas of race and class" (Spivak, An Aesthetic Education 363). Spivak anticipates something more than a direct allegorical equivalence between "received ideas" such as race, class or nation, and the characters on the page. If ethics and, indeed, being human means that one is "angled toward an other and others" (352), then the constitution of being-in-relation to others cannot be achieved in a strictly representationalist mode that, as in Casanova, grounds that relation in an assumed notion of the nation. Since "[b]y definition, we cannot - no self can - reach the quite-other [...] the ethical situation can only be figured in the ethical experience of the impossible. And literature, as a play of figures, can give us imaginative access to the experience" (352). In other words, if a writer like Achebe is, as Casanova suggests, representative of his nation and, in turn, his work in its peripheral, deprived status posits a direct correlation between content and the voice of the people then this makes a very particular demand with respect to our idea of the writer in relation to those others that he or she seeks to represent. The question posed previously - to what extent does Achebe represent a new Nigeria? - gains further significance. If to be human is to be "angled towards" but always prevented from fully reaching the other, then the ethical literary response to one's own situated experience must be one that opens up to the imaginative experience of the impossible, the unforeseeable and the new. The nation by this account is, then, "a collective project yet to come" and a site of potentiality as Jameson suggests. Without reducing the singularity of literature, at such moments the text opens up to an otherness that exceeds it, "signalling beyond itself [...] with an eye to the future anterior, exceeding one's grasp" (Spivak, An Aesthetic Education 367).

In "The Stakes of a World Literature" Spivak begins to trace the contours of the world literary space in terms of a tension between the particular spaces occupied by each experiencing being and a singular, irreducible space. Any text can be read and in the process "help experiencing beings fill up the gaps in presupposing a world" (An Aesthetic Education 457). The literary text, therefore, enables the reader to encounter an alterity that can be made 
productive in the constitution of their own "world" ("every experiencing being [...] assumes a world" [457]). In other words, the reader does not simply find in the text a mirror of the world as they see it (the same), but an experience of difference that becomes part of the production of their world and its on-going refigurment (change). Each text can serve this function because "[a] repeatable difference inhabits each" (458); a space that is "not only everdifferent but also ever-repeatable. [...] That is the space where the 'creative', the excess [...] lodges" (458). This account of singularity promotes it as a shared space of difference, as the capacity of language and therefore literature to both challenge the dominant order of things (as difference) and participate in the on-going renewal of a specific experiencing being's world (as repetition). As such, Casanova's demands for a reconstituted link between world and text, specific and singular, is anticipated here by Spivak. However, I would suggest that this is a move that, despite both Casanova's and Spivak's arguments to the contrary, finds common ground in the philosophy of Deleuze.

\section{World Literature as Minor Literature}

In little less than two pages Casanova dismisses Deleuze and Guattari's concept of minor literature as a misrepresentation of Kafka's comments on literature. In her wake, Christopher Prendergast happily proclaims that "Casanova junks the Deleuzian assimilation of small to minority as a category-mistake, producing an image of Kafka as a prophetic revolutionary quite at odds with his real preoccupations" ("The World Republic of Letters" 15). At issue is the question of the specific relation between literature and politics, and indeed, by extension the distinction between literature as representation (a reflection of nationalist sentiment) and as revolutionary creation (productive of a nation that is yet-to-come). Casanova limits her interrogation of Deleuze and Guattari's concept of minor literature to their co-authored Kafka. Minor, as it is used in this work, is said to refer to "the revolutionary condition of all literature" rather than being aligned with specific literary or national contexts, a distinction that allows Deleuze and Guattari to read Kafka, Casanova claims, as "a political author who had no real political interests, who did not care about the burning political questions of his time" (The World Republic 204) (i.e. nationalism). Spivak takes much more care in her reference to Deleuze, outlining his concept of singularity as irreducible to "the particular because it is an 
unrepeatable difference that is, on the other hand, repeated - not as an example of a universal but as an instance of a collection of repetitions [...]. Singularity is life as pure immanence" (An Aesthetic Education 430). As implied above, the idea in Deleuze that singularity designates a shared, virtual plane which, as such, plays a crucial role in the nondialectical production of the new, has some purchase on Spivak's discussion of singularity. Like Deleuze, Spivak is concerned to by-pass dialectical difference as the perpetuation of an imperialist framework, rejecting the idea of "the self-consolidating other as the self's mere negation" (340), and arguing that alterity "is not our dialectical negation" (339) even while it makes an ethical demand upon us to live in relation to others. Singularity, by both accounts, is tied to the non-dialectical production of difference because it inheres in a shared plane that is immanent to all. As in the discussion of literature above, Spivak's subaltern is singular both as an "unrepeatable difference" which "cannot be generalized according to hegemonic logic" (430) and as "a category and therefore [as] repeatable" (430). This marks the limits of Spivak's engagement with Deleuze since "any differentiation between subalternity and the popular must thus concern itself with singular cases and thus contravene the philosophical purity of Deleuze's thought" (431).

In different ways, both Casanova and Spivak ultimately reject Deleuze's philosophy on grounds that recall Peter Hallward's indictment - his thought ultimately leads us out of this world. In Casanova, her conflation of majoritarian and minoritarian forms of politics misrepresents the political as exclusively an act of deterritorialisation or counter-actualisation. For Spivak, the subaltern "may be a version of [Deleuzian] singularity" insofar as it "cannot be generalized according to hegemonic logic" (430), but ultimately the purity of Deleuze's philosophy cannot take into account the singular case which can only be grasped in terms of its absolute particularity. In a similar vein, Jacques Rancière criticises Deleuze's reading of Melville in Essays Critical and Clinical by suggesting that his work fails to live up to the philosophical purity of minor literature: for all his focus on deterritorialising sounds and stutters, Deleuze always returns us to figures of language (cf Rancière, Dissensus 180). Between these two positions, then, I would argue that while the "minor" is indeed the revolutionary capacity in literature, it is nevertheless always a case of mediating between the singular and the specific. "Singularity is life as pure immanence", but Deleuze stresses that it 
is always a negotiation between life as singularity and as lived particularity. As he notes in his reading of Our Mutual Friend:

Between [Riderhood's] life and his death, there is a moment that is only that of a life playing with death. The life of the individual gives way to an impersonal and yet singular life that releases a pure event freed from the accidents of internal and external life, that is, from the subjectivity and objectivity of what happens. [...] The life of such individuality fades away in favor of the singular life immanent to a man who no longer has a name [...]. A singular essence, a life. (Pure Immanence 28-9)

In passages such these Deleuze emphasizes the central notion that 'life' has two concurrent senses in his philosophy: this particular life (the individuated instance of actual being) and $a$ life (virtual, pre-personal and singular life). As an immanent and absolutely other plane of difference, the latter - $a$ life - represents the ever-present potential for (or eternal return of) new, unpredictable forms of actual life.

In turn, if literature is no mere reflection of the world it is because it embodies a singularity (a life) that is the power to become. However, it is the writer's task to bear witness to that singular life and, crucially, what it reveals about this world. The writer, Deleuze argues in a discussion of Melville in Essays, does so by witnessing figures of "primary nature" (singular life):

Ishmael in Moby-Dick, Captain Vere in Billy Budd, and the attorney in Bartleby all have this power to "See": they are capable of grasping and understanding, as much as is possible, the beings of Primary Nature [...]. Though they are able to see into the Primary Nature that so fascinates them, they are nonetheless representatives of secondary nature and its laws [...]. Torn between the two Natures, with all their contradictions, these characters [...] are Witnesses, narrators, interpreters. (Essays Critical and Clinical 80-1) 
I would suggest that Deleuze remains compatible with Spivak's notion of singularity precisely because of this distinction between the eccentric figures of primary nature and the role of the prophet, which is to bear witness to the effects of originals as well as the light they throw on the world. "The novelist has the eye of a prophet, not the gaze of a psychologist" (82): in other words, the prophetic role of the author stems from their ability to intuit a singular life - an unrepeatable difference that is nevertheless repeated - from their particular experience of the world. It is this distinction that gives the writer a creative, affirmational, productive role rather than, to recall the earlier discussion of Nietzsche, a reactive, representational one. The writer, Deleuze will also argue, is a symptomatologist who draws from their experience of the world to create new concepts that allow us to better understand the illnesses of man (cf Deleuze, Essays 3). That experience is an encounter with everyday actuality (being), but one that, at the same time, also intuits, as far as possible, the singular life beyond, and to that extent "[w]riting is inseparable from becoming" (1). Becoming designates the revolutionary potential of literature, "when [literature] discovers beneath apparent persons the power of an impersonal" (3). The "power" may lie with the latter, but one begins nonetheless with the specific ("apparent persons"). At once, then, the author both draws from their experience of the particular "cases" that they encounter and intuits something of the immanent singular life behind them, an experience of alterity which underlies their creative will-to-power.

Deleuze's concept of singularity in a literary context, then, is one that anticipates the demands for newness, fragmentation and a creolising concept of identity that postcolonial thinkers pose. As the writer moves from the particular case to the singularity which grounds it, a revolutionary refiguring of the status quo is made possible without leading out of this world or contravening the philosophical purity of pure immanence. By the same token, the political function of minor literature may lie in its disruptive capacity, but it is not the case that politics is only ever revolutionary. In "Bartleby, or The Formula" it is the American Revolution that provides Deleuze with his example of the way in which literature participates in a re-imagining of the world, capturing the potentiality of a more equal society that is yet to come, and that is, crucially, always at risk of returning to the majoritarian hegemony. In the same sense that Glissant will contrast the rhizome and the tree, the former providing the image of thought behind his concept of Relation (cf Poetics of Relation 11), and challenge the foundational idea 
of paternity and filiation as an imperialist mode of conceiving the nation (cf Caribbean Discourse 73), Deleuze privileges affiliation and becoming as an escape from majoritarian nationalism. In Glissant, the atavistic model is one which assumes an "uninterrupted lineage from father to son, with no illegitimacy", a colonialist mind-set which not only "authorizes an aggrandizement of territory [...] but it also foresees what is to come, what is going to be conquered, and what is going to be discovered" (Faulkner Mississippi 114). Glissant here reminds us of what is at stake in the deterritorialisation of the nation and models of paternity: not simply that images which replicate the figure of the nation (in "Bartleby" or Kafka the Law, portrait and above all the father serve this function) participate in the creation of a hegemonic "now", but of a future that is a continuation of that model. What is to come is a repetition of the same, the perpetuation of that lineage. The nation as a majoritarian form produces a predictable, foreseeable future that cannot meet the demand for newness, difference and a creolised people yet-to-come that distinguish the postcolonial proper.

That which is minor and revolutionary, then, remains of greatest interest to the postcolonial critic just as it defines Deleuze and Guattari's minor literature. If literature embraces the power of a singularity - "[a] brother, a sister, all the more true for no longer being 'his' of 'hers'” (Deleuze, Essays Critical and Clinical 84) - it does so, however, in the hope of realising an actual "society of brothers" (84). Far from enforcing the philosophical priority or purity of the virtual or singular, Deleuze's thought explores the space in-between the specific and the singular, where the singular power of "a brother" is threatened with the return of the paternal function (88), and, conversely, where the majoritarian image of the nation or the father is deterritorialised. This two-way process is evident, Deleuze suggests, in the failed promise of the American Revolution: an attempt to "transform the world, to think a new world or new man insofar as they create themselves" (86); "a new community" based on a non-hierarchical relation of members rather than filial ties. To the extent that American literature is caught up in a process of transformation, it makes a "democratic contribution" (87) to the figuring of a new community (a people yet-to-come) "where every element has a value in itself but also in relation to others" (86). If, in the case of America, that revolutionary potential faltered with "the restoration of the nation-state" and the return of "the monstrous fathers" (88), its promise persists nonetheless: 
For even in the midst of its failure, the American Revolution continues to send out its fragments, always making something take flight on the horizon [...], always trying to break through the wall, to take up the experiment once again, to find a brotherhood in this enterprise, a sister in this becoming, a music in its stuttering language. (89)

Immanent to the majoritarian political formation of the nation-state is the potential for minor becomings as the former's undoing, and as the possibility of a people without fathers, who, bearing in mind Nietzsche's sense of active/reactive forces, create themselves. Minor and major here coexist within this example of political struggle: Deleuze may favour experimental becomings, but once again they stem from an encounter with majoritarian states of affairs. As before, it is the preservation of the tension between the singular and the specific that is key. Both poles are essential in the process that continually confronts literature with its other and opens up a space for the production of a yet-to-come (postcolonial or otherwise) that is much more than a continuation of the same - a "peculiar space, of a future that is not a future present" (Spivak, An Aesthetic Education 66).

Despite some scepticism over the application of Deleuze's philosophy to postcolonial and world literature debates, it is my conviction that we have much to gain from a deep understanding of the way in which his work contributes to an immanent philosophy of difference, creation and the new. Deleuze's critique of dialectical concepts of difference, for example, can productively engage with Spivak's planetarity as an "alterity [that] remains undivided from us, [which] is not our dialectical negation" (339). To think "the world, not just the nation-state" is to "imagine anew imperatives that structure all of us" (350): this move finds resonance not only with Glissant's thought (as Spivak acknowledges) but with Deleuze's in his characterisation of the world as caught up in a non-dialectical process of becoming or counter-/actualisation. Where Deleuze defines his democratic vision of the nation as a collection of fragments without hierarchy, a "society of brothers [where] alliance replaces filiation" (Essays Critical and Clinical 84), "a wall of loose, uncemented stones, where every element has a value in itself but also in relation to others" (86), both Spivak and Glissant in different ways suggest that a concept of relation and the experience of alterity might be tied to 
an ethical vision. In making such a claim both reject a Levinasian form of ethics in which the "recognition of the other" effects "a moral obligation (which would be a banality)" (Glissant, Poetics of Relation 29). Rather, a creative dimension is stressed: "encountering the Other superactivates poetic imagination and understanding" (29) precisely because what is encountered is a singularity, or what Glissant will call, an opacity. Demanding "the right to opacity" (190) recognises that the acceptance of difference in itself is not enough to break free from imperialist structures of thought. The self might be accepting of difference but it remains tied to binary thinking: even without prejudice "I relate it [difference] to my norm. I admit you to existence, within my system. I create you afresh. - But perhaps we need to bring an end to the very notion of a scale" (190). Relational or planetary thinking abandons the very "notion of a scale" in the sense that the latter creates a transcendental norm ("my system") against which everything else is judged. This is precisely the problem that Deleuze addresses: the father, the law or the nation-state organise the world in relation to their own fixed, transcendental values. Deleuze will therefore reject judgement because it "presupposes pre-existing criteria (higher values), criteria that pre-exist for all time" (Essays Critical and Clinical 134) and, thus, "prevents the emergence of any new mode of existence. For the latter creates itself through its own forces, that is, through the forces it is able to harness" (135). To judge is to presuppose "pre-existing criteria" or a "notion of scale" against which beings are measured - a reactive state of affairs in which the individual is defined first by what they are not. To the extent that postcoloniality might be conceived of as a condition of prevailing active forces, embracing the power of transformation and of creativity - "imagin[ing] anew imperatives that structure all of us" (Spivak, An Aesthetic Education 350) - then "[i]t is not a question of judging other existing beings, but of sensing whether they agree or disagree with us, that is, whether they bring forces to us, or whether they return us to the miseries of [colonisation]" (Deleuze, Essays Critical and Clinical 135). The Spivakian/Glissantian ethical relation in which the whole "notion of scale" is abandoned in favour of a singular conception of difference is, through Deleuze, implicitly bound to the concepts of creativity, newness and the affirmational will-to-power.

The implication of this reading of alterity and relation bares significance not only on current debates in postcolonial studies, however, but also on those concerning world 
literature. Critiques of Casanova's The World Republic, for example, and in particular, those which pick up on what Casanova refers to as the Greenwich Meridian of Literature - a point of orientation within the world republic of letters - resonate with Glissant's rejection of difference. ${ }^{11}$ As a fixed ground which relativizes the literary world, the Greenwich Meridian institutes a scale and brings the whole constellation of world literature into relation (not necessarily hierarchically) with Casanova's own Eurocentric norm. Elaborating this point, Casanova illustrates her concept through the idea of a woven rug in which many strands together form an image:

from the right angle, the carpet will suddenly present the attentive observer with "the one right combination" of "superb intricacy" - an ordered set of motifs which can only be understood in relation to each other, and which only become visible when perceived in their totality, in their reciprocal dependence and mutual interaction. [...] Each figure can be grasped only in terms of the position it occupies within the whole, and its interconnections with all the others. (Casanova, "Literature as a World" 73)

As a metaphor for the relation between literary critic and the world, the carpet poses an image of thought that bears some resemblance to Deleuze's patchwork or "wall of loose, uncemented stones" (86). Here Casanova imagines a totality in which each individual part is grasped both in terms of its particular position within the whole and in terms of its relation to others, a move that finds common ground with Deleuze's concept of the world as process and as fragment. In turn, this archipelagic model might be productive for a revised understanding of world literature as a collection of parts "where every element has value in itself but also in relation to others" (Deleuze, Essays Critical and Clinical 86). However, this can only take us so far. If "[e]ach figure can be grasped only in terms of the position it occupies with the whole", then the position of the reader or critic who "grasps" is no less significant. As Buescu notes, Casanova's Greenwich Meridian posits “an ideal single vantage point (France and, more specifically, Paris) from which the 'figure in the carpet' (to use the metaphor she borrows from Henry James) might be understood, whereas the reality is that different vantage points generate different competing descriptions and multiple worlds" ("Pascale Casanova" 
130). Building on this, I would suggest that Casanova makes the "Whitmanian" mistake, as Deleuze sees it, of "plac[ing] the Idea of the Whole beforehand" when "it turns out that a kind of whole must be constructed, a whole that is all the more paradoxical in that it only comes after the fragments and leaves them intact" (58). An ideal vantage point from which to evaluate and judge presupposes a pre-existing set of criteria (the whole); a shifting focus, as noted by Buesce, "generate[s] different competing descriptions and multiple worlds" and is, by contrast, best understood as an unceasing process by which the whole is constructed.

This distinction, I would further suggest, might be developed through Glissant's Poetics of Relation where "Relation" is a whole that "does not precede itself in its action and presupposes no a priori" (172): "The difference between Relation and totality lies in the fact that Relation is active within itself, whereas totality, already in its very concept, is in danger of immobility" (171). As a collection of fragments, then, Relation denotes a process by which the whole is constructed and reconstructed with no a priori basis. Glissant's incomplete totality (Relation), then, would seem to anticipate Casanova's model of the world literary space with the caveat that in Glissant the "Greenwich Meridian" is itself part of the whole that is constantly changing and constructed anew. To the degree that figures or stable points emerge within Relation they are conceived as a form of conatus described as "échos-monde": "In order to cope with or express confluences, every individual, every community, forms its own échos-monde" (Poetics of Relation 93). Despite this desire for coherence, however, these figures can never constitute an ideal or a priori norm because they are opaque. Relation is the process by which a non-pre-existing whole is constructed from opacities or "irreducible singularit[ies]" (190). In a description that foreshadows Casanova's Jamesian metaphor of the rug, Glissant describes how "[o]pacities can coexist and converge, weaving fabrics. To understand these truly one must focus on the texture and the weave and not on the nature of its components. [...] Thought of self and thought of other here become obsolete in their duality" (190). Opacity approximates Glissant's concept of creolisation as an identity in process, changing and becoming new in an unpredictable, affiliative rather than filiative manner. In other words, opacity and singularity must be taken in the Spivakian/Deleuzian sense of an ever-repeated difference. Alterity is detransendentalised in this move because it is immanent to the planetary whole - "it contains us as much as it flings us away" (Spivak, An 
Aesthetic Education 339). For Spivak, as for Glissant, the ethical response to the other must recognise this immanence and moreover resist the reification of the self through an openness to uncertainty, change and an unknown future yet to come. Where Casanova fails to live up to her relational figures in the carpet and her attempt to return to a model of literary analysis that both preserves the singularity of literature and restores the link between world and text, is in the moment that the potentiality of the "yet to come" shifts wholly into the singular world republic, measured as a distance from the specifying force of the nation. By Casanova's account, the "purity" of the world literary space is contravened when the revolutionary force of singularity returns to the specific. In this sense, Casanova privileges world literary singularity as a transcendence out of this world: a move that Spivak is right to resist in her formulation of a planetary thinking that is once an experience of the impossible and an ethical relation to the other. This is not, however, a flaw I find in Deleuze, and with Glissant he shares an understanding of immanent difference as the potential for revolutionary newness in this world, as the promise of a postcolonial future yet-to-come.

\section{Works Cited}

Achebe, Chinua. Things Fall Apart. London: Heinemann, 1962.

Ahmad, Aijaz. "Jameson's Rhetoric of Otherness and the 'National Allegory". Social Text. 17 (1987): 3-25.

Benítez-Rojo, Antonio. "Creolization and Nation Building in the Hispanic Caribbean". Trans. James Maraniss. Sisyphus and Eldorado: Magical and Other Realisms in Caribbean Literature. Ed. Timothy Reiss. Trenton, NJ: Africa World Press, 2002. 17-28.

Bignall, Simone. Postcolonial Agency: Critique and Constructivism. Edinburgh: Edinburgh UP, 2010.

Buescu, Helena Carvalhao. "Pascale Casanova and the Republic of Letters". The Routledge Companion to World Literature. Ed. Theo D'haen, David Damrosch and Djelal Kadir (London and New York: Routledge, 2014) 126-135.

Bongie, Chris. Friends and Enemies: The Scribal Politics of Post/Colonial Literature. Liverpool: Liverpool University Press, 2008.

Burns, Lorna. Contemporary Caribbean Writing and Deleuze. London: Continuum, 2012.

Casanova, Pascale. "Literature as a World”. New Left Review 31 (2005): 71-90.

Casanova, Pascale. The World Republic of Letters. Trans. M.B. DeBevoise. Cambridge, MA: Harvard University Press, 2004. 
Césaire, Aimé. Discourse on Colonialism. Trans. Joan Pinkham. New York and London: Monthly Review Press, 1972.

Deleuze, Gilles. Essays Critical and Clinical. Trans. Daniel Smith and Michael Greco. Minneapolis: University of Minnesota Press, 1997.

Deleuze, Gilles. Negotiations: 1972-1990. Trans. Martin Joughin. New York: Columbia University Press, 1995.

Deleuze, Gilles. Nietzsche and Philosophy. Trans. Hugh Tomlinson. London and New York: Continuum, 2006.

Deleuze, Gilles. Pure Immanence: Essays on A Life. Trans. Anne Boyman. New York: Zone Books, 2005.

Deleuze, Gilles and Claire Parnet. Dialogues II. Trans. Hugh Tomlinson and Barbara Habberjam. London and New York: Continuum, 2006.

Edmunds, Lowell. "Kafka on Minor Literature". German Studies Review. 33.2 (2010): 351 374.

Glissant, Édouard. Caribbean Discourse: Selected Essays. Trans. J. Michael Dash.

Charlottesville: University Press of Virginia, 1989.

Glissant, Édouard. "Creolization and the Making of the Americas". Race, Discourse and the Origin of the Americas: A New World View. Ed. Vera Lawrence Hyatt and Rex Nettleford. Washington: Smithsonian Institute Press, 1995. 268-275.

Glissant, Édouard. Faulkner, Mississippi. Trans. Barbara Lewis and Thomas Spear. New York: Farrar, Straus and Giroux, 1999.

Glissant, Édouard. Poetic Intention. Trans. Nathalie Stephens. Callicoon, NY: Nightboat Books, 2010.

Glissant, Édouard. Poetics of Relation. Trans. Betsy Wing. Ann Arbor, MI: University of Michigan Press, 1997.

Hardt, Michael. Gilles Deleuze: An Apprenticeship in Philosophy. London: UCL Press, 1993.

Harris, Wilson. Jonestown. London: Faber and Faber, 1996.

Hallward, Peter. Absolutely Postcolonial: Writing Between the Singular and the Specific. Manchester: Manchester UP, 2001.

Hallward, Peter. Out of this World: Deleuze and the Philosophy of Creation. London and New York: Verso, 2006.

Hiddleton, Jane. "Spivak's 'Echo': Theorizing Otherness and the Space of Response". Textual Practice. 21.4 (2007): 263-640.

Huddart, David. Postcolonial Theory and Autobiography. London: Routledge, 2008.

Jameson, Fredric."Third-World Literature in the Era of Multinational Capitalism". Social Text 15 (1986): 65-88.

Larsen, Neil. Determinations: Essays on Theory, Narrative and Nation in the Americas. London: Verso, 2001.

Lazarus, Neil. "Fredric Jameson on ‘Third World Literature': A Qualified Defence”. Fredric 
Jameson: a Critical Reader. Ed. Sean Homer and Douglas Keller. Basingstoke: Palgrave, 2004. 42-61.

Memmi, Albert. The Colonizer and the Colonized. Trans. Howard Greenfield, London: Souvenir Press, 1974.

Nesbitt, Nick. Caribbean Critique: Antillean Critical Theory from Toussaint to Glissant. Liverpool: Liverpool UP, 2013.

Parry, Benita. Postcolonial Studies: a Materialist Critique. London: Routledge, 2004.

Prendergast, Christopher. "The World Republic of Letters". Debating World Literature. Ed. Christopher Prendergast. London: Verso, 2004.1-25.

Rancière, Jacques. Dissensus: On Politics and Aesthetics. Trans. Steven Corcoran. London: Continuum, 2010.

Renan, Ernest. 'What is a Nation?' Trans. Martin Thom. Nation and Narration. Ed. Homi Bhabha. London: Routledge, 1990. 8-22.

Spivak, Gayatri. An Aesthetic Education in the Era of Globalization. Cambridge MA: Harvard UP, 2013.

Walcott, Derek. What the Twilight Said. New York: Farrar, Strauss and Giroux, 1999.

\begin{abstract}
${ }^{1}$ To this list of Caribbean thinkers, I would add Antonio Benítez-Rojo for whom creolisation names "not a process - a word that implies forward movement - but a broken series of recurrences, of happenings, whose only law is change" ("Creolization and Nation-Building" 19); Aimé Césaire who argued in Discourse on Colonialism that "the problem is not to make a utopian and sterile attempt to repeat the past, but to go beyond. [...] It is a new society that we must create" (31); and Derek Walcott, whose work takes up a creative engagement with the past and colonial canon, refusing to see literature is simply a site of colonial oppression (cf What the Twilight Said 62).
\end{abstract}

${ }^{2}$ As Deleuze argues, Nietzsche rereads the Hegelian master-slave dialectic in terms which privilege the affirmational will-to-power in contrast to a reactive state of affairs, characteristic of both the slave and the master (cf Deleuze, Nietzsche 9). Thus, "the Nietzschean notion of the slave does not necessarily stand for someone dominated, by fate or social condition, but also characterises the dominators as much as the dominated once the regime of domination comes under the sway of forces which are reactive" (Deleuze, Nietzsche ix).

3 "I could not stand Descartes, the dualisms and the Cogito, or Hegel, the triad and the operation of the negative. But I liked writers who seemed to be part of the history of philosophy, but who escaped from it in one respect, or altogether: Lucretius, Spinoza, Hume, Nietzsche, Bergson" (Deleuze and Parnet, Dialogues //11). For further discussion of the implications for postcolonial thought of a dialectical philosophy ultimately aimed at the recuperations of difference, see Bignall (2010).

${ }^{4}$ Spivak, in rather harsh terms, rejects Hallward's book as one which "carries the mark of a dissertation, and is contained within a specific academic debate, unrelated to the concerns of this book [An Aesthetic Education]" (581). The slighting of Absolutely Postcolonial's significance is unwarranted, and elsewhere others have recognised (though not necessarily wholly agreed with) Hallward's distinctive contribution to the field (cf Nesbitt, Caribbean Critique 262-270; Burns, Contemporary Caribbean Writing and Deleuze 11-20; Hiddleton 624-625; Bongie, Friends and Enemies; Huddart, Postcolonial Theory and Autobiography). 
Furthermore, and as I hope shall become clear in the following discussion of singularity in Spivak and Deleuze, the concerns of Hallward's Absolutely Postcolonial are ones he holds in common with the work of Spivak.

${ }^{5}$ For Hallward, Deleuze offers a philosophy that "lead[s] out of the world" (Out of This World 3 ) since it conceives production as that which "does not in itself depend on mediation through the categories of representation, objectivity, history or the world" (5).

${ }^{6}$ Prendergast echoes this implicit critique of Deleuze and Guattari's translation of klein as minor and not small; on the other hand, Lowell Edmunds writes that "[w]hile it is true that Kafka was thinking of the literature of peoples numerically small, [...] the fact remains that 'minor' is the standard translation of the German klein" ("Kafka on Minor Literature" 356. Edmunds specifically discusses Casanova's reading of "minor" and Deleuze in this essay). Whichever side of the argument one falls down upon such a exercise in "chasing signifiers" is about as far from Deleuze and Guattari's literary-critical project as one can get: the question they seek to answer is not what did Kafka really mean?, but what philosophical concept can we create from his work? (On this definition of literature and philosophy, see their co-authored What is Philosophy?; on the "depraved" act of "set[ting] off after signifiers" [Deleuze, Negotiations 7-8], see "Letter to a Harsh Critic").

${ }^{7}$ As, of course, articulated in the often-anthologised essay of that name (cf Renan, "What is a Nation?").

${ }^{8}$ This is, of course, the novel's famous claim - "The white man is very clever. He came quietly and peaceably with his religion. We were amused at his foolishness and allowed him to stay. Now he has won our brothers, and our clan can no longer act as one" (Achebe, Things Fall Apart 124) - but further it is noted that the kotma or court messengers are distinguished by being "foreigners" (123) to Umofia, in other words, from other tribes and different regions.

${ }^{9}$ This is echoed by Buescu: "Casanova starts from the concept of nation and builds her argument on the idea that the dynamics of the literary system may be fully explained through the rivalries and competitions between nations and their national literatures (one per nation)" (“Pascale Casanova and The Republic of Letters" 129).

${ }^{10}$ Aijaz Ahmad provides a forceful critique of Jameson's blanket claim for all third world literature, as well as the binary of first and third worlds upon which this distinction rests. Jameson, Ahmad claims, defines both first and second worlds according to their modes of production (one capitalist, the other socialist), while the third world is defined purely by its experience of colonisation. From Ahmad and Jameson's Marxist perspective, since human history is the history of class struggle under capitalism, this model places the third world outside of history: a colonialist move. If the third world is defined by an experience of colonialism, by a relation of domination from elsewhere, "then what else can one narrate but that national oppression? Politically, we are Calibans all" (Ahmad, "Jameson's Retoric" 102). Neil Lazarus, on the other hands, offers a rejoinder to Ahmad in this respect and his essay provides a good overview of this debate (cf Lazarus, "Frederic Jameson").

${ }^{11}$ See, for example, Prendergast ("The World Republic" 8-9) or Buescu ("Pascale Casanova" 129-130). 